\title{
THE TRANSFORMATION IN PUBLIC FINANCE ADMINISTRATION
}

\author{
Oğuz OYAN ${ }^{1}$
}

\begin{abstract}
The political/administrative regime in Turkey has been radically transformed with the Constitutional Referendum held on 16 April, 2017. The new initiative nominalized a parliamentarian system which has been developed since 1876 with ups and downs, a constitutional legal order which came into being and developed with the Republic and the principle of the separation of powers brought by the 1961 Constitution.

The system foreseen by the new Constitution was even beyond this: extreme concentration of power within the execution itself. In the Presidential Government System, the role of ministers turned into ordinarily appointed civil servants and they have lost their ability to assemble regularly, make decisions, prepare draft laws and submit them to the Parliament as a council. The administrative mentality in Presidential Government System does not rely on the principle of merit, instead, the relations in Presidential Government System are characterized with clientelism, nepotism and ideological affinities.

The primary aim of this paper is to draw a framework for the transformation in public economic/public finance administration model and to do a critical analyze of the extent to which a monocratic model of administration can be a functional and to what extent it can remain outside of intra institutional conflicts. The main conclusion of this paper will be to state that Turkey's priority is nothing other than to change this third world presidency regime and its administrative structure.
\end{abstract}

Keywords: Presidential Government System (PGS), presidential decree (PD), statuary decree (SD), new administrative model, clientelism

Jel Codes: $\mathrm{H}, \mathrm{H} 11, \mathrm{H} 83, \mathrm{Z18}$.

\section{Introduction}

Although Law No: 6771 which was presented to the referendum consisted only of 18 items, it touched upon the $79^{\text {th }}$ bylaw of the constitution which in fact consists of a total of 177 items. (Aydın, 2017, 5). However, the more important transformation took place in the qualitative sense.

The constitutional amendment adopted in 2017 put another nail in the coffin of the principle of the separation of powers (checks and balances) introduced by the 1961 Constitution (and sustained by subsequent amendments adopted in the 1982 Constitution). The new initiative was designed to bury the parliamentarian system into history which has been progressed for 140 years and cease the advance of democratization which the 1961 Constitution substantially paved the way. ${ }^{2}$ The relations between the Council of Ministers and the Government-Parliament which historically constituted the central element of the parliamentarian system were bypassed by removing the Council of Ministers and the institution of the Prime Minister's Office from the political system. A new public administration structure centered on presidency was built instead.

\footnotetext{
1 Retired Prof., Ankara University, Social Sciences Faculty, Department of Public Finance, oguzoyan@gmail.com

2 In the general preamble of Law No: 6771, the 1961 Constitution is clearly being targeted. For a further thought on this issue, see: Oyan, 2017.
} 
Although the legislature has been at the disposal of execution since before 2017, the new amendments put higher judicial bodies under the control of privileged executive power. A new Presidential administration model has been built which overthrew the hierarchy and distribution of responsibilities even within the executive power itself and removed the Council of Ministers and the Prime Minister's Office from decision making process and thus destroyed the equilibrium inside the executive power.

\section{Constitutional and Legal Basis of the New Presidential System}

\subsection{Constitutional Basis}

The constitution of the new regime 'approved' on 16 April, 2017 became effective in three stages. Some of its provisions became effective immediately upon the finalization of the referendum results, some (only 4 provisions) on 30 April, 2018 when the legal calendar of the Presidential election process became valid and lastly, the remaining numerous provisions became effective on 9 July, 2018 when the President took oath and began his official duty in the aftermath of the 24 June, 2018 elections. Since the adjustment laws in relation to the constitutional provisions enacted in the first stage had failed to pass on time, the process was accelerated following the amendments which became effective with all their provisions in the third stage.

The Constitution which can be referred as the "Constitution of the Second Republic" became effective with all of its provisions as of 9 July, 2018 on which the President took oath and assumed his duties. After this date, the new institutional structuring of the state gained an incredible speed.

\subsection{Formation of a Republic of Decrees ${ }^{3}$}

The Statutory Decree (SD) No: 703 which was published on 9 July, 2018 in the Official Gazette, legislated both the adjustment laws and some additional regulations at the same time. The SD No. 703 transformed the structures of councils/institutions and while some of the councils were changed in terms of their scope and title some of them were abolished (SD, No:703, Article 60) (for instance State Planning Organization). All kind of relations between institutions/councils with the Presidency or the ministries has been restructured (SD, No: 703, Article 41/b and its continuation). Above all the President became the sole determinant power to decide on the components of some councils/institutions such as the Economic and Social Council (SD, No:703, Article 109/b).

Successively four Presidential Decrees (PD) were published under the heading of "Presidential Decrees on the Presidential Organization" in the Official Gazette dated on 10 July, 2018, which formed the basis of the new organizational structure. In particular the first of these Decrees, which were numbered from 1 to 4, was the most basic one with its 539 articles.

Under the new PGS, 16 ministries have been decided to work under the direct command of the President. Furthermore, nine "board of politics" and four "Presidential Offices" were established and the President has gained the exclusive right to appoint their chairmen and members. In addition to that, 11 "institutions, councils and funds" have been subjected to the direct domination of the President. Thus, while the new government system steered towards over-

\footnotetext{
3 The Statutory Decrees (SD) and Presidential Decrees (PD) mentioned and analyzed here are as follows: SD, No:
} 700 (2018); SD, No: 703 (2018); PD, No: 1, 2, 3, 4 (2018) and PD, No: 13 (2018). 
centralization on the one hand, the decision making mechanism in public services was shared out and distributed to the ministries together with numerous councils, offices and directorates on the other hand. What is more, as there were other councils besides the aforementioned ones, there were councils which were active and affiliated to the ministries as well.

\section{The New Administrative Model of Public Economy}

\subsection{Ministries, Councils, Offices, Directorates, etc.: A Chaotic Structure}

There was a quite chaotic picture even in terms of public finance administration: In addition to the ministries related to economy, the structures directly associated with the Presidency needed to be taken into consideration now. The regulations regarding the ministries constituted the most predominant part (PD, No: 1, Articles 38-502). Eight of the 16 ministries were directly or indirectly related to the management of economy. These were:

\section{The Ministry of Treasury and Finance,}

\section{Ministry of Trade,}

\section{Ministry of Industry and Progress,}

Ministry of Energy and Natural Resources,

Ministry of Transportation and Infrastructure,

Ministry of Environment and Urbanization,

Ministry of Agriculture and Forestry,

Ministry of Labor, Social Services and Family.

Councils, offices and directorates functioning in economics which were under the direct control of the President instead of ministries were as follows:

Directorate of Strategy and Budget,

Council of Economic Policies,

Council of Social Policies,

Council of Health and Food Policies,

Council of Science, Technology and Innovation Policies,

Office of Finance,

Office of Investment,

Office of Digital Transformation...

The decision making processes on the management of economy seemed more branched out compared to their trial during Turgut Özal's period in the 1980's. (Oyan \& Aydın, 1991; and Oyan, 2014). A chaotic structure, in which frequent conflicts related to decisions or conflicts took place, was being formed. 
The first reason why this structure carried chaotic characteristics was that, a hierarchical order between ministries which were all associated with the presidency and councils/offices/directorates had not been foreseen. The early emergence of authority conflicts between ministries and councils which had great structural differences was almost inevitable. For instance, according to PD, No: 1, Article 21, the President was entitled as the chairman of all political councils, however these councils consisted of at least three members (yes, only three!) and one of the members served as deputy chairman.

Political councils are placed as if they were in higher ranks vis-à-vis ministries in the hierarchy. In fact, the deputy chairman of the councils is mostly acting as the representative of the President and his or her rank in hierarchy is, at least, accepted as equivalent to a minister. It would indeed be a kind of optimism to assume powerful ministerial organizations consisting of hundreds of experts who have been strongly committed to their departments and gained experience throughout in decades and also to assume ministers who strive hard to remain at the top of the hierarchy in accordance with the very nature of politics and its deep-seated manner and customs, to unconditionally yield to the bureaucratic councils composed of three people. If we were to consider the issue in the reverse manner, it would be meaningless to assume that a political council consisting of three members could have competed with the capacities of a ministerial organization.

As for the institutions and organizations linked to the President, their total number reaches to 11 , eight of which are directorates, one is an institution, one is a general directorate and one is a fund. Most have their own special law and since they were taken over from the old structure with the exception of the "Ministry of Strategy and Budget" and "Ministry of Communication," these institutions and organizations which have preserved their unique mode of operation still have a common point: according to PD, No: 3 , the President is determinant in the appointment of their presidents and high ranking executives. In the meantime, the Turkish Wealth Fund was linked to the Presidency, the President was entitled to manage the fund and the Minister of Treasury and Finance (the son-in-law of the President) was appointed by the President as the acting chair of the fund. This case provides other clues about the personal aspect of this government model.

On the other hand, the Ministry of Treasury and Finance, which has been organized almost as a "primus inter pares" in terms of scope of duties and authorities, embodies certain councils within its body. The New Economic Program (NEP) which was announced on 20 September, 2018 and identical to the Medium Term Program (but contains anti-crisis precautions as well) defined councils of the new economy within the body of this ministry as follows:

- Public Finance Transformation and Change Office (TCO): Its duty is to program the transformation of savings and incomes;

- Turkish Financial Services Committee: Its duty is to regulate and inspect financial services;

- Financial Stability and Progress Committee (FSPC): Its duty is to maintain financial security and stability.

Apparently, the Ministry was forming new offices and councils (under the counsel of McKinsey) to put into shape the disorderly public finance administration structure! TCO was partially taking over the authority of ministries, councils, offices and directorates affiliated with the Presidency, because it would be serving as a monitoring, guiding, supervising and reporting unit for financial policies as well. 
The inflated number of councils was not limited with these. Numerous councils from the previous period affiliated with the President, whose members as a whole or in majority would now be appointed by the President, still existed (SD, No: 703, Articles 135, 149, 162-171).

\subsection{Conflict/Disagreement Areas in the New Government System}

The decision making processes in relation only to finance administration seemed even more branched out compared to the past. In addition to that, the Central Bank of the Republic of Turkey which was a part of the previous structure and the Directorate of Privatization Administration which was reorganized with PD, No: 4 and similar directorates together with old or new organizational structures affiliated to the ministries were to be taken into consideration.

To have an initial idea about the strange "hierarchical" relationships among the newly formed structures, let us take a look at the "Coordination Meetings" which regulated the Political Councils (PD, No:1, Article 32/1): "The related ministers can organize coordination meetings with the senior administrators of institutions and organizations with the attendance of the related political council's acting president, with the purpose of ensuring coordination pertaining to the duties and activities in common areas. The guidelines determined at these meetings are presented to the President." And PD: 1, Article 32/2: "The President or the acting president of the political council appointed by the President or the minister presides over the coordination meetings." Also PD: 1, Article 32/3: "All activities and procedures related to the coordination meetings are carried out by the related political council."

As for the duties and authorities of the offices, it is stated in the $7^{\text {th }}$ paragraph of Article 528 titled "Responsibility and Coordination" of PD, No: 1 that: "The Office is in charge of and responsible for coordinating all institutions and organizations in terms of issues related to its area of duty and for ensuring coordination and holding the required meetings and other organizations." Whether the "political council" or the "office" will take precedence about holding the coordination meeting have been left to the director's and his or her administrators' skill of reaching the President!

In fact, it can be seen in the $22^{\text {nd }}$ Article of PD, No: 1 which regulates the "General duties and authorities of councils" that, the reiterated duty and authority areas between these and the presidential offices are much more in number than the ones indicated here. Of course, we are left with a difficult equation if we add on top of these, the Directorate of Strategy and Budget and the Directorate of Communication which are the two directorates newly formed within the scope of "affiliated institutions and councils" which can be intermixed with the offices and political councils.

We should also add that a powerful administrative structuring and a wide range of duties and authorities have been foreseen for the "Strategy and Budget Directorate" which is one of the new directorates (PD, No: 13). In fact, there are five general directorates, one department, two consultancies and a private secretariat among the service units of this directorate and somehow it was formed as if it was a combination of a mini Ministry of Treasury and Finance and the old State Planning Organization. This "Directorate," which was given the task of preparing jointly with the Ministry of Treasury and Finance the medium term program, the medium term financial plan, the Presidential annual plan, the sectoral plan and programs (PD, No: 13, Article 2/a) and the central administration budgetary law proposal draft (PD, No: 13, Article 2/h). Thus the Directorate would need a great bureaucratic organization in parallel to the ministry within its 
body to be able to achieve all these great tasks. However, since the Directorate has not been able to complete these tasks, it inevitably transferred its areas of duty to the Ministry of Treasury and Finance for the 2019 documents ${ }^{4}$.

Thus, the idea of "politics not putting up with gaps" was valid for bureaucracy as well. The delays -in the appointment of the administrators of the councils and offices formed within the scope of the Presidency or the laxity in the formation of the organizations which remained too slow compared to the issuing of the Decrees gave the first signs of the gaps. On the other hand, the coming of the fore of politic affinities/favoring kith and kin in the appointment process rather than merit made the bureaucratic shield of the President (wished to surround himself) quite fragile. If you did not have a plan to completely overthrow the state, it could not be expected for "bureaucratic oligarchy" which the party member President obsessively attributed to the ministries (it is very likely that this reflected the outpouring of fears), to remain non-functional in against to the sloppy formed political councils and offices.

Finally, it may spring to mind that the problems can easily be solved by taking into consideration that the final decision authority in the case of decision making conflicts is a single man shining like the sun on top of the government plan. It can even be considered that this chaotic decision making structure has been especially planned to emphasize the indispensable role of this one man and to remind the capitalist class members of this role. ${ }^{5}$ The result does not change; there still remains a designed governmental organization plan which would always be open to the new arm-wrestling matches of politics and inner-bureaucracy.

\subsection{PGS Paves the Way to a Monolithic Administrative Tyranny}

The President's appetite for governing and appointing is not limited with the abovementioned councils, institutions, organizations and offices. According to the $9^{\text {th }}$ paragraph of Article 104 of the Constitution, the president, "He/she shall appoint and dismiss the high ranking executives, and shall regulate the procedure and principles governing the appointment thereof by presidential decree." These decrees are PD, No: 2 and PD, No:3 dated 10 July, 2018.

It can be seen that the scope of the "high ranking executives" in PD, No: 3 is quite extensive. The length of the lists in the attached tables (I) and (II) reveal this situation. In table (I), there is a total of 75 positions, however only 45 of these is related to singular appointments and 30 are related to multiple appointments. The term singular appointment refers mainly to the appointment of presidents/heads/directors. Multiple appointments refer to positions which concern more than one person, such as presidents, acting presidents, members, governors, ambassadors, permanent representatives/delegates, rectors and presidents of inspection boards of ministries. Thus, it was made possible for the President to directly appoint high ranking executives to hundreds of positions. What is more, the assignments of a much larger

\footnotetext{
4 Detailed expert views on the 2019 documents (budget, Medium Term Program, Medium Term Financial Plan and others) can be followed from the articles of Konukman (2018) who has been focusing on this area since the middle of 2018 which are published in BirGün Newspaper.

5 While it could be assumed that the structuring of the new government and the appointment of the Son-in-law Minister to the top of the administration of economy would greatly please a small part of the capitalist group, it at the same time might disquiet those who had more distant relations with the government or those who found it safer to reach the political arena from multiple channels for their own interests. However, when the known adaptation speed of the capital is taken into consideration, it would not be surprising for the gap to close rapidly.
} 
group consisting of the highest ranking administrator positions indicated in Table (II) can only be done with the approval of the President.

Other than these, public banks, public economic enterprises (SD, No: 703, Articles 132 and 133), Directorate of Privatization Administration (PD, No: 4), administrative boards, councils and committees (PD, No: 1, Articles 521-523), Savings Deposit Insurance Fund in which the president and all of its members are appointed by the President (PD, No: 3, Article 2/2, Table I) and certain institutions/boards linked to ministries and other public establishments should be listed as well. Without doubt, there are more important ones: Many members of the Higher Judicial Bodies are determined by the President. As mentioned earlier, the same situation is valid for all of the university rectors now. Likewise, according to PD, No: 3, Article 9, the provision states that "Promotions to higher ranks and appointments for generalship and admiralty are done by the President."

The established Presidential government structure resembles an organigram plan with a single center and limitless number of branches. There does not seem to be any institutions or organizations which the President does not interfere with in terms of their formation and decision making process.

Perhaps what is more important is that, the employee personal and retirement rights of "high ranking executives" such as wage and working hours being determined by the President arbitrarily, can change depending on the position or the person (PD, No: 3, Articles 5 and 6). ${ }^{6}$ The assignments of former politicians to high ranking positions in public establishments indicate that these arbitrary decisions are necessary to ensure the political loyalty of the high ranking executives to the President. Turkey is rapidly joining to the ranks of the autocratic third world countries in respect of his administrative system.

\section{Conclusion}

The administrative mentality in PGS does not rely on the principle of merit, instead, the relations in PGS system are characterized with clientelism, nepotism, fellow-townsmenship, all ways of favoritism including kinship and identity relationships and ideological affinities. In concomitant with that, denunciation, defamation and discretization are also being conducted in order to take over as high ranking positions or to eliminate other nominees. Healthy organizational structures and functions derived from this spoiled structure which totally excludes the principle of merit can only depend on chance from now on.

The administrative structure of PGS, corresponds to an over centralized and disorganized type of structure and it manages as if it was trying to carry out "divide" and "rule" understanding in real politics. There are limitations in terms of putting this structure into shape in the future with certain legal interventions; this path in the existing constitutional order is blocked. What is more, as new regulations aiming at disciplining local administrations even more and placing them under the administrative tyranny of a partisan President leading the ruling party, it does not seem possible for this public administration model "to be corrected" in the legal platform. Turkey's priority is nothing other than to change this dictatorial regime or this "third world countries presidency regime" (Tunaya, 1980) and its administrative structure, PGS, in a radical manner; this can only be possible with a brand new constitution.

\footnotetext{
${ }^{6}$ For a more detailed article on these issues, see: Oyan, 2019, pp.105-125.
} 


\section{References}

Aydın, A.R. (2017). “Mühendislikten 'Anayasa'ya, Anayasızlaştırmadan 'Mühendis'liğe”, (“From the Enginery to the 'Constitution', from the Deconstitutionilisation to the 'Enginery' "), EMO Dergisi, (March), pp. 5-9.

Konukman A. (2018). Birgün Gazetesi 2018 yazıları. (Articles published on Birgün newspaper in 2018).

Law No: 6771 (2017), “TC Anayasasında Değişiklik Yapılmasına Dair 6771 sayılı Kanun” (Law Corcerning the Amendments to the Turkish Republic Constitution"), law adopted on 21th January 2017 and offert to the referendum at $17^{\text {th }}$ April 2017.

Oyan O., \& Aydın A.R. (1991) Türkiye'de Maliye ve Fon Politikaları; Alternatif Yönelişler (Public Finance and Public Founds Politics in Turkey; Alternative Ways), Ankara, Adım Yayıncılık.

Oyan O. (2014). “Kamu Yönetiminde Neo-Liberal Dönüşüm: 1923-2013” (“Neoliberal Transformation in Public Administration: 1923-2013), (Ed.) Demirci, A.G., Ergüzeloğlu Kilim E. \& Dik E., in Prof. Dr. Tayfur Özşen Anısına 70. Yaş Armağanı, Ankara, pp. 116-133.

Oyan, O. (2017). "Anayasa Referandumu, Rejim Değişikliğinin Son İki Hamlesinden Illkidir" ("The Constitutional Referendum is the First of Two Moves of the Regime Change"), Sosyal Demokrat, (March-April), pp. 22-26.

Oyan, O. (2019). "Yeni Anayasa ve Yeni Devlet Yapılanması" ("The New Constitution and the New State Structuring"), Çalışma ve Toplum, Ekonomi ve Hukuk Dergisi, DiSK/ Birleşik Metal-iş, (60), pp.105-125.

PD, No: 1 (2018). Presidential Decree issue 1, in Official Gazette of July 10, 2018.

PD, No: 2 (2018). Presidential Decree issue 2, in Official Gazette of July 10, 2018.

PD, No: 3 (2018). Presidential Decree issue 3, in Official Gazette of July 10, 2018.

PD, No: 4 (2018). Presidential Decree issue 4, in Official Gazette of July 10, 2018.

PD, No: 13 (2018). Presidential Decree issue 13, in Official Gazette of July 24, 2018.

SD, No: 700 (2018). Statutory Decree issue 700, in Official Gazette of 7 July, 2018.

SD, No: 703 (2018). Statutory Decree issue 703, in Official Gazette of 9 July, 2018.

Tunaya, T. Z. (1980). Siyasal Kurumlar ve Anayasa Hukuku (Political Institutions and Constitution Law), İstanbul, Fakülteler Matbaası, Fourth ed., pp. 395-96. 